Jurnal Abdidas Volume 2 Nomor 3 Tahun 2021 Halaman 676-683

JURNAL ABDIDAS

http://abdidas.org/index.php/abdidas

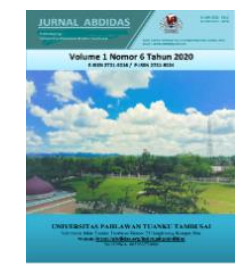

\title{
Penyuluhan Hukum Terkait Penggunaan Dana Desa di Tengah Pandemi Covid-19
}

\author{
Yusrizal $^{1 \bowtie}$, Hadi Iskandar $^{2}$, Zulkifli $^{3}$, Romi Asmara $^{4}$, Ferdy Saputra $^{5}$, Hasan Basri ${ }^{6}$, Muhammad Nasir $^{7}$ \\ Hukum, Fakultas Hukum, Universitas Malikussaleh, Indonesia ${ }^{1,2,3,4,5,6,7}$ \\ E-mail: yusrizal@unimal.ac.id ${ }^{1}$, hadi.iskandar@unimal.ac.id², zulkifli@unimal.ac.id ${ }^{3}$, \\ romi.asmara@unimal.ac.id ${ }^{4}$, ferdy@unimal.ac.id ${ }^{5}$, hasanbasri@unimal.ac.id ${ }^{6}$, $\underline{\text { muhammadnasir@unimal.ac.id }}^{7}$
}

\begin{abstract}
Abstrak
Dana desa yang diberikan oleh pemerintah seringkali tidak terkelola dengan baik. Penggunaan dana desa yang tidak maksimal serta sesuai kebutuhan masyarakat disinyalir menjadi penghambat kemajuan desa. Dalam rangka mensukseskan program dana desa ini, tim pelaksana kegiatan pengabdian kepada masyarakat Fakultas Hukum Universitas Malikussaleh mengadakan "Penyuluhan Hukum Terkait Penggunaan Dana Desa di Tengah Pandemi Covid19". Kegiatan penyuluhan hukum ini dilakukan dengan menggunakan metode ceramah dan diskusi. Peserta penyuluhan hukum diberikan pemahaman mengenai penggunaan dana desa sesuai dengan peraturan perundang-undangan serta variasi penggunaan dana desa. Selanjutnya, peserta penyuluhan hukum diberikan kesempatan untuk bertanya serta mendiskusikan persoalan yang berkaitan dengan kebijakan prioritas penggunaan dana desa di tengah pandemi Covid-19, kegiatan diskusi ini dilakukan sebagai bagian dari menjaring persoalan yang terjadi dalam masyarakat, khususnya Desa Mon Geudong, Kota Lhokseumawe. Kegiatan penyuluhan hukum terkait penggunaan dana desa dan tupoksi di tengah pandemi Covid-19 di Desa Mon Geudong, Kota Lhokseumawe berjalan dengan baik. Hasil penyuluhan hukum yang didapatkan adalah adanya perubahan pola penggunaan anggaran desa untuk yang sifatnya produktif. Dapat disimpulkan dari kegiatan ini, semua peserta penyuluhan sangat antusias mengikuti acara hingga selesai dan merasakan manfaat penyuluhan hukum bagi perencanaan dan kemajuan desa demi kesejahteraan masyarakat. Banyak pertanyaan yang muncul terkait persoalan desa, masyarakat mengharapkan supaya kampus jangan meninggalkan desa dan terus bersinergi dalam pembinaan sumberdaya manusia serta penyuluhan-penyuluhan hukum yang sangat banyak memberikan manfaat, terutama kondisi ditengah pandemi-Covid-19.
\end{abstract}

Kata kunci: penyuluhan hukum, dana desa, Covid-19

\begin{abstract}
Village funds provided by the government are often not well managed. The use of village funds that are not maximal and according to the needs of the community is signaled to be an obstacle to the progress of the village. In order to succeed this village fund program, the team implementing community service activities of the Faculty of Law, Malikussaleh University held a "Legal Counseling Related to the Use of Village Funds In the Midst of the Covid-19 Pandemic". This legal counseling activity is conducted using lecture methods and discussions. Participants of legal counseling are given an understanding of the use of village funds in accordance with the laws and regulations as well as variations in the use of village funds. Furthermore, participants of legal counseling were given the opportunity to ask questions and discuss issues related to the priority policy of using village funds in the midst of the Covid-19 Pandemic, this discussion was conducted as part of capturing the problems that occurred in the community, especially Mon Geudong Village, Lhokseumawe City. Legal counseling activities related to the use of village funds and toxicology in the midst of the Covid-19 pandemic in Mon Geudong Village, Lhokseumawe City are going well. The result of legal counseling obtained is a change in the pattern of use of village budgets for productive ones. In conclusion from this activity, all participants of the counseling are very enthusiastic to follow the event to the end and feel the benefits of legal counseling for the planning and progress of the village for the welfare of the community. Many questions arise related to village issues, the community expects that the campus should not leave the village and continue to synergize in the development of human resources and legal counseling that provides many benefits, especially in the midst of the Covid-19 Pandemic.
\end{abstract}

Keywords: legal counseling, village fund, Covid-19

Copyright (c) 2021 Yusrizal, Hadi Iskandar, Zulkifli, Romi Asmara, Ferdy Saputra, Hasan Basri, Muhammad Nasir $\triangle$ Corresponding author

Address : Gampong Paloh Lada, No. 188, Aceh Utara

Email : yusrizal@unimal.ac.id

DOI : https://doi.org/10.31004/abdidas.v2i3.339

ISSN 2721-9224 (Media Cetak)

ISSN 2721- 9216 (Media Online) 
677 Penyuluhan Hukum Terkait Penggunaan Dana Desa di Tengah Pandemi Covid-19- Yusrizal, Hadi Iskandar, Zulkifli, Romi Asmara, Ferdy Saputra, Hasan Basri, Muhammad Nasir

DOI: https://doi.org/10.31004/abdidas.v2i3.339

\section{PENDAHULUAN}

Tujuan dari diberikannya otonomi daerah adalah dimaksudkan untuk meningkatkan pelayanan dan pengelolaan sumber daya alam agar bisa dilakukan secara lebih efektif. Dalam hal ini, Mardiasmo mengemukakan bahwa tujuan utama otonomi daerah adalah untuk meningkatkan pelayanan publik (public service) dan untuk memajukan perekonomian daerah, melalui tiga misi utama yaitu, meningkatkan kualitas dan kuantitas pelayanan publik, menciptakan efisiensi dan efektifitas pengelolaan sumber daya daerah, memberdayakan dan menciptakan ruang yang lebih luas untuk masyarakat untuk berpartisipasi dalam proses pembangunan. Untuk mencapai tujuan-tujuan tersebut maka tentu saja diperlukan pengelolaan keuangan daerah termasuk pengelolaan keuangan di desa dengan baik (Mardiasmo, 2002) .

Pembangunan desa akan semakin menantang di masa depan dengan kondisi perekonomian daerah yang semakin terbuka dan kehidupan berpolitik yang lebih demokratis. Akan tetapi, desa sampai saat ini masih belum beranjak dari profil lama yakni terbelakang dan miskin. Meskipun banyak pihak mengakui bahwa desa mempunyai peranan yang besar bagi kota, namun tetap saja desa dipandang rendah dalam hal ekonomi ataupun hal yang lainnya. Padahal kita ketahui bahwa sebagian besar penduduk Indonesia berdiam di daerah pedesaan dan berprofesi sebagai petani dan nelayan. Oleh karena itu, sudah sewajarnya bila pembangunan pedesaan harus menjadi prioritas utama dalam segenap rencana strategi dan kebijakan pembangunan di Indonesia (Hernowo, 2004).

Melihat penyelenggaraan pemerintahan desa berdasarkan asas desentralisasi sebagai bagian dari pemerintahan daerah. Bila dahulu desa hanya sebagai objek pembangunan oleh pemerintahan daerah, sekarang menjadi subjek pembangunan yang mengelola desa secara mandiri. Konsekuensi logis desa sebagai subjek pembangunan yang mandiri, menuntut pemerintah desa harus mampu menyusun dokumen perencanaan dan anggaran sendiri. Dokumen perencanaan pembangunan desa disusun berdasarkan aspirasi masyarakat desa melalui musyawarah pembangunan masyarakat desa. Hal ini juga harus didukung oleh pemahaman masyarakat mengenai tugas pokok dan fungsi masyarakat yang bertugas sebagai aparatus desa (Karepowan, 2020).

Berdasarkan belakang tersebut, maka sebagai upaya sadar perlu dilakukan oleh perguruan tinggi untuk melakukan penyuluhan hukum di Desa Mon Geudong, Kota Lhokseumawe terkait "Penyuluhan Hukum Terkait Penggunaan Dana Desa di Tengah Pandemi Covid19". Alasan dilakukan penyuluhan hukum dilakukan di desa tersebut karena adanya permintaan dari tokoh-tokoh masyarakat didesa tersebut untuk memberikan pemahaman mengenai aturan hukum penggunaan dana desa serta bagaimana pemanfaatan dana tersebut tepat sasaran sesuai kebutuhan masyarakat.

Sasaran dari kegiatan tersebut merupakan bagian dari bentuk penyuluhan yang akan memberikan pemahaman dan berkontribusi terkait penggunaan dana desa. Hal tersebut dilakukan 
678 Penyuluhan Hukum Terkait Penggunaan Dana Desa di Tengah Pandemi Covid-19- Yusrizal, Hadi Iskandar, Zulkifli, Romi Asmara, Ferdy Saputra, Hasan Basri, Muhammad Nasir

DOI: https://doi.org/10.31004/abdidas.v2i3.339

supaya dalam proses perumusan kebijakan prioritas penggunaan dana desa dirasakan bermanfaat bagi masyarakat sebagai upaya menuju desa yang mandiri.

\section{METODE}

Pelaksanaan kegiatan pengabdian kepada masyarakat ini dilaksanakan di Balai Pertemuan Desa Mon Geudong, Lhokseumawe. Khalayak sasaran yang diundang pada penyuluhan ini adalah perangkat desa dan pemuda di Desa Mon Geudong, Lhokseumawe. Pelaksanaan kegiatan pengabdian pada masyarakat ini dilakukan dengan menggunakan metode ceramah dan diskusi. Metode ceramah, peserta diberikan motivasi dan pemahaman mengenai penggunaan dana desa sesuai dengan peraturan perundang-undangan. Selain itu, peserta diberikan materi tentang pentingnya memahami tugas pokok dan fungsi dalam mengemban amanah sebagai aparatus desa. Selanjutnya metode diskusi yaitu, peserta penyuluhan hukum diberikan kesempatan untuk mendiskusikan permasalahan yang berkaitan dengan kebijakan prioritas penggunaan dana desa di tengah Pandemi Covid-19, serta berbagai permasalahan yang terkait dengan hukum yang selama ini mereka dihadapi, hal ini juga sebagai bagian dari menjaring persoalan yang terjadi dalam masyarakat.

Adapun manfaat kegiatan penyuluhan hukum ini secara umum akan memberikan manfaat terkait hal-hal apa saja yang menjadi kebijakan prioritas dana desa bagi aparatur desa. Secara khusus, sebagai penguatan dan pemahaman mengenai tugas dan fungsi sebagai aparatur, sehingga proses menjadi desa penggunaan keuangan desa semakin baik.

Kegiatan akhir penyuluhan hukum adalah evaluasi terhadap pelaksanaan kegiatan pengabdian. Evaluasi tersebut dimaksud sebagai bentuk koreksi terhadap proses pelaksanaan pengabdiannya ke depannya. Hasil evaluasi penyuluhan hukum masyarakat sangat terbantu dengan pemahaman kebijakan prioritas penggunaan dana desa di masa pandemi Covid-19. Bahkan Kepala Desa Mon Geudong, mengharapkan ke depannya adanya kerjasama yang lebih serius lagi untuk menjadikan desa binaan dan kesadaran hukum masyarakat antara Fakultas Hukum Universitas Malikussaleh dan Desa Mon Geudong, Kota Lhokseumawe.

\section{HASIL DAN PEMBAHASAN}

Kegiatan penyuluhan hukum terkait penggunaan dana desa di tengah pandemi covid-19 dilakukan di Desa Mon Geudong, Kota Lhokseumawe, Provinsi Aceh. Kegiatan ini dilaksanakan bagi perangkat/aparatur desa dan pemuda. Bentuk kegiatan dilaksanakan dengan pemaparan materi penyuluhan dengan menghadirkan ahli dari Lembaga Kajian dan Konsultasi Hukum Lhokseumawe. Kegiatan ini diadakan pada hari Senin, 16 November 2020 di Balai Pertemuan Desa Mon Geudong. Penyuluhan hukum ini dilakukan dengan pengayaan materi pengantar penggunaan dana desa di masa Pandemi Covid-19. 
679 Penyuluhan Hukum Terkait Penggunaan Dana Desa di Tengah Pandemi Covid-19- Yusrizal, Hadi Iskandar, Zulkifli, Romi Asmara, Ferdy Saputra, Hasan Basri, Muhammad Nasir

DOI: https://doi.org/10.31004/abdidas.v2i3.339

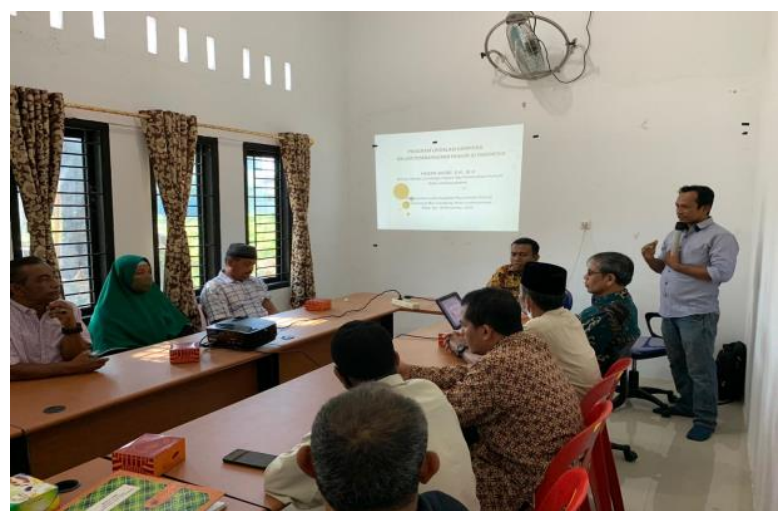

Gambar 1: Kegiatan Pembukaan Kegiatan

Perihal pengelolaan Keuangan Desa harus dikelola berdasarkan praktik-praktik pemerintahan yang baik. Asas-asas Pengelolaan Keuangan Desa sebagaimana tertuang dalam Permendagri Nomor 113 Tahun 2014 yaitu transparan, akuntabel, partisipatif serta dilakukan dengan tertib dan disiplin anggaran, dengan uraian sebagai berikut (Indrianasari, 2017):

1. Transparan yaitu prinsip keterbukaan yang memungkinkan masyarakat untuk mengetahui dan mendapat akses informasi seluas-luasnya tentang keuangan desa. Asas yang membuka diri terhadap hak masyarakat untuk memperoleh informasi yang benar, jujur, dan tidak diskriminatif tentang penyelenggaraan pemerintahan desa dengan tetap memperhatikan ketentuan peraturan perundang-undangan;

2. Akuntabel yaitu perwujudan kewajiban untuk mempertanggungjawabkan pengelolaan dan pengendalian sumber daya dan pelaksanaan kebijakan yang dipercayakan dalam rangka pencapaian tujuan yang telah ditetapkan. Asas akuntabel yang menentukan bahwa setiap kegiatan dan hasil akhir kegiatan penyelenggaraan pemerintahan desa harus dapat dipertanggungjawabkan kepada masyarakat desa sesuai dengan ketentuan peraturan perundang- undangan;

3. Partisipatif yaitu penyelenggaraan pemerintahan desa yang mengikutsertakan kelembagaan desa dan unsur masyarakat desa;

4. Tertib dan disiplin anggaran yaitu pengelolaan keuangan desa harus mengacu pada aturan atau pedoman yang melandasinya.

Menurut Pasal 71 UU I Nomor 6 Tahun 2014, Keuangan desa adalah semua hak dan kewajiban desa yang dapat dinilai dengan uang serta segala sesuatu berupa uang dan barang yang berhubungan dengan pelaksanaan hak dan kewajiban desa. Menurut UU Desa, Pasal 72 ayat (1) pendapatan desa bersumber dari (Supriadi, 2015):

1. Pendapatan asli desa terdiri atas hasil usaha, hasil aset, swadaya dan partisipasi, gotong royong, dan lain-lain pendapatan asli desa;

2. Pendapatan asli desa terdiri atas hasil usaha, hasil aset, swadaya dan partisipasi, gotong royong, dan lain-lain pendapatan asli desa;

3. Alokasi Anggaran Pendapatan dan Belanja Negara;

4. Bagian dari hasil pajak daerah dan retribusi daerah kabupaten/kota;

5. Alokasi dana desa yang merupakan bagian dari dana perimbangan yang diterima kabupaten/kota; 
680 Penyuluhan Hukum Terkait Penggunaan Dana Desa di Tengah Pandemi Covid-19- Yusrizal, Hadi Iskandar, Zulkifli, Romi Asmara, Ferdy Saputra, Hasan Basri, Muhammad Nasir

DOI: https://doi.org/10.31004/abdidas.v2i3.339

6. Bantuan keuangan dari Anggaran Pendapatan dan Belanja Daerah Provinsi dan Anggaran Pendapatan dan Belanja Daerah Kabupaten/Kota;

7. Hibah dan sumbangan yang tidak mengikat dari pihak ketiga; dan lain-lain pendapatan desa yang sah.

Pendapatan asli desa adalah pendapatan yang berasal dari kewenangan desa berdasarkan hak asal usul dan kewenangan skala lokal desa. Yang dimaksud dengan "hasil usaha" termasuk juga termasuk hasil BUM desa dan tanah bengkok. Anggaran yang bersumber dari Anggaran Pendapatan dan Belanja Negara (APBN) tersebut adalah anggaran yang diperuntukkan bagi desa dan desa adat yang ditransfer melalui Anggaran Pendapatan dan Belanja Daerah Kabupaten/Kota yang digunakan untuk membiayai penyelenggaran pemerintahan, pembangunan, serta pemberdayaan masyarakat, dan kemasyarakatan. Besaran alokasi anggaran yang peruntukannya langsung ke desa ditentukan 10\% (sepuluh perseratus) dari dan di luar dana transfer daerah (on top) secara bertahap (Wahyuningtyas, 2021).

Oleh sebab itu, dana desa sebagai salah satu tujuan pembangunan desa yang merupakan bagian integral dari pembangunan nasional dalam rangka otonomi daerah. Pembangunan desa mempunyai peranan yang sangat penting dan strategis dalam rangka Pembangunan Nasional dan Pembangunan Daerah, karena di dalamnya terkandung unsur pemerataan pembangunan dan hasil-hasilnya serta menyentuh secara langsung kepentingan sebagian besar masyarakat yang bermukim di perdesaan dalam rangka upaya meningkatkan kesejahteraan mereka (Ratnadila, 2018).

Kegiatan ini juga melibatkan peran beberapa mahasiswa Fakultas Hukum Universitas Malikussaleh sebagai ajang memperdalam pemahaman mengenai dana desa di masa pandemi Covid-19. Hal ini dilakukan dalam upaya untuk memperkenalkan kampus merdeka, merdeka belajar dalam masyarakat (Lili, 2018).

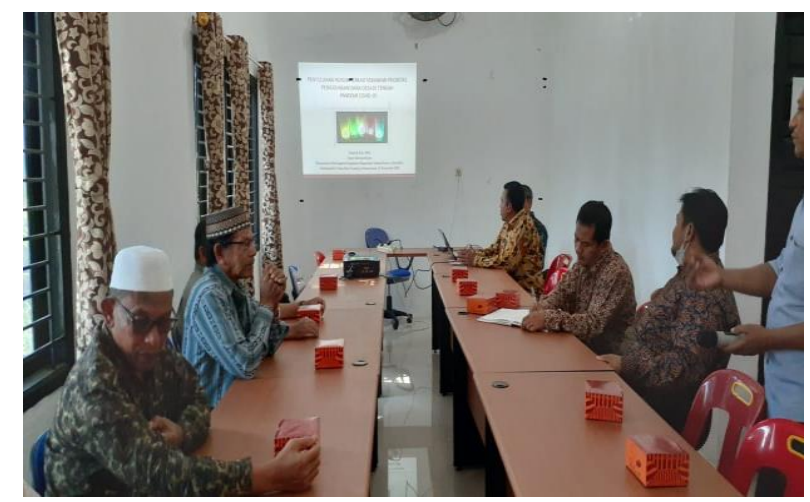

Gambar 2: Kegiatan Pemberian Materi Penyuluhan

Kegiatan penyuluhan hukum ini diikuti oleh Kepala Desa, Sekretaris Desa, Tuha Peut (Badan Permusyawaratan Desa), serta Ketua Pemuda beserta seluruh aparatur Desa Mon Geudong lainnya. Kegiatan ini dilaksanakan di Balai Pertemuan Desa Mon Geudong, Kota Lhokseumawe. Dalam penyampaian penyuluhan hukum dijelaskan bahwa sejak diberlakunya Undang-Undang Republik Indonesia Nomor 6 Tahun 2014 tentang Desa yang disertai dengan Peraturan Pemerintah Nomor 43 Tahun 2014 tentang Peraturan Pelaksanaan UU Nomor 6 Tahun 2014 tentang desa, maka desa memiliki kewenangan sebagai daerah otonom. Desa diberikan kesempatan yang besar untuk mengurus 
681 Penyuluhan Hukum Terkait Penggunaan Dana Desa di Tengah Pandemi Covid-19- Yusrizal, Hadi Iskandar, Zulkifli, Romi Asmara, Ferdy Saputra, Hasan Basri, Muhammad Nasir

DOI: https://doi.org/10.31004/abdidas.v2i3.339

pemerintahan sendiri, termasuk melaksanakan pengelolaan keuangan. pengelolaan keuangan desa kemudian diatur dalam Peraturan Menteri Dalam Negeri Nomor 113 tahun 2014 tentang Pengelolaan Keuangan Desa yang dananya bersumber dari APBN dan sumber lainya. Desa yang tidak terbiasa dengan sistem keuangan negara dikhawatirkan belum siap melakukan pengelolaan keuangan desa dengan baik. Di sisi lain, karena ada hak anggaran maka desa harus ditata. Penataan itu harus memenuhi unsur tata kelola yang baik, artinya tata kelola yang sesuai dengan aturanaturan yang berlaku untuk membangun kemandirian. Kemandirian desa dibangun dengan konstruksi menggabungkan fungsi self-governing community, dengan local self government.

Diharapkan kesatuan masyarakat hukum adat yang selama ini merupakan bagian dari wilayah desa, ditata sedemikian rupa menjadi desa dan desa adat.

Kegiatan penyuluhan hukum ini mendapat apresiasi dan respon positif terkait aparatur desa. Kegiatan ini sangat bermanfaat bagi desa dalam mengelola dan menggunakan dana desa dimasa pandemi Covid-19. Aparatur desa berharap supaya kegiatan tersebut tidak berhenti satu kali saja, namun kalau sepakat dijadikan program untuk pembinaan terkait penggunaan dana desa. Kepala desa dan perangkatnya mempunyai tugas berat dalam menjalankan roda pemerintahan di tingkat desa. Saat ini, desa dituntut mampu mengelola anggaran pemerintah yang nilainya cukup besar, Sehingga kepala desa dan perangkatnya mesti lebih meningkatkan kapasitas Sumber Daya Manusia (SDM).

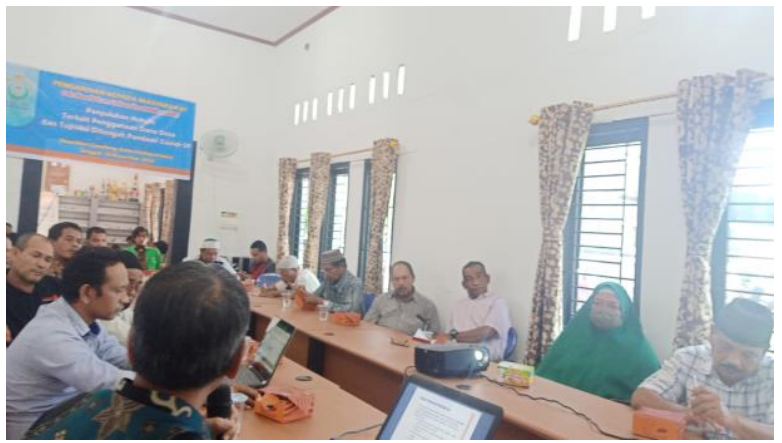

Gambar 3: Kegiatan Sesi Diskusi

Pada saat sesi diskusi, muncul berbagai persoalan serta banyaknya tantangan yang harus dihadapi oleh masyarakat Mon Geudong Kota Lhokseumawe. Oleh sebab itu, karena desa harus bisa memetakan potensi yang dimiliki desa, serta harus mampu menggali prakarsa desa, mendorong partisipasi, hingga tercapainya keberdayaan desa. Seringkali juga muncul benturan dengan peraturan pemerintah daerah/qanun, untuk itu perlu upaya sinkronisasi agar tidak terjadi kendala saat mengimplementasikan tata kelola desa. Dalam penyampaian diskusi tersebut, Pemteri menyebutkan bahwa, ada tiga pilar dalam desa yaitu Pemerintah Desa (Pemdes), masyarakat, dan Lembaga Kemasyarakatan Desa. Di desa ada forum resmi yang digunakan sebagai penyambung aspirasi masyarakat, berupa musyawarah desa, musyawarah dusun, dan musyawarah rencana pembangunan desa (Musrembangdes), yang akan menghasilkan dokumen Rencana Pembangunan Desa, RKPDesa, dan APBDesa. 
682 Penyuluhan Hukum Terkait Penggunaan Dana Desa di Tengah Pandemi Covid-19- Yusrizal, Hadi Iskandar, Zulkifli, Romi Asmara, Ferdy Saputra, Hasan Basri, Muhammad Nasir

DOI: https://doi.org/10.31004/abdidas.v2i3.339

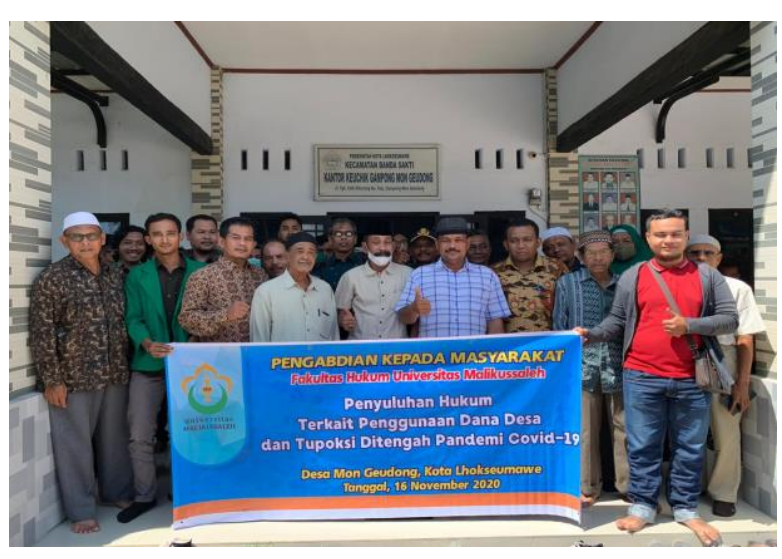

Gambar 4: Sesi Photo Bersama Selesai Kegiatan

Melalui dokumen-dokumen tersebut, dan didukung oleh anggaran, harapannya pembangunan yang dilaksanakan di desa benarbenar partisipatif, transparan dan dapat dipertanggungjawabkan. Desa tidak semata-mata bicara dana desa, tapi bagaimana peradaban desa dapat diwujudkan. Pada sesi terakhir, masyarakat sangat mengharapkan kegiatan ini terus dapat dijalankan dan dijadikan program yang berkelanjutan terutama untuk membina desa. Masyarakat juga meminta supaya ada kerjsama antara desa dengan perguruan tinggi terutama Fakultas Hukum Universitas Malikussaleh yang sudah menjadi pelopor dalam memberikan pemahaman terhadap kebijakan dana desa di masa Covid-19.

\section{SIMPULAN}

Kegiatan terkait penggunaan dana desa dan tupoksi di tengah pandemi Covid-19 di Desa Mon Geudong, Kota Lhokseumawe dalam pelaksanaan berjalan dengan lancar. Semua peserta kegiatan penyuluhan sangat antusias mengikuti acara hingga selesai dan merasakan manfaat penyuluhan hukum dalam penggunaan dana desa serta pemahamam mengenai masing-masing tugas pokok dan fungsi dalam rangka menciptakan desa yang mandiri dan berdikari dengan memaksimalkan dana desa dan potensi desa. Hal yang harus dilaksanakan ke depannya supaya kegiatan ini terus berkelanjutan, serta peran aktif desa untuk terus melakukan kolaborasi dengan perguruan tinggi perlu ditingkatkan lagi.

\section{UCAPAN TERIMA KASIH}

Kegiatan penyuluhan hukum ini terlaksana berkat dukungan dari Rektor Universitas Malikussaleh, Aceh, Ketua Lembaga Penelitian dan Pengabdian Masyarakat, Dekan Fakultas Hukum, Lembaga Kajian dan Konsultasi Hukum Lhokseumawe, Ketua Pemuda Desa Mon Geudong Lhokseumawe yang telah coba menginisiasi kegiatan ini beserta seluruh perangkat desa setempat serta Mahasiswa Fakultas Hukum yang aktif membantu dalam mengikuti kegiatan ini.

\section{DAFTAR PUSTAKA}

Hernowo, B. (2004). Kajian pembangunan ekonomi desa untuk mengatasi kemiskinan. Artikel Jurnal, 1(1).

Indrianasari, N. T. (2017). Peran Perangkat Desa Dalam Akuntabilitas Pengelolaan Keuangan Desa (Studi Pada Desa Karangsari Kecamatan Sukodono). Jurnal Ilmiah Ilmu Akuntansi, Keuangan Dan Pajak, 1(2).

Karepowan, A. A. C. (2020). PENGATURAN HUKUM KEUANGAN DESA MENURUT UNDANG-UNDANG NOMOR 6 TAHUN 2014 TENTANG DESA. LEX ADMINISTRATUM, 8(4).

Lili, M. A. (2018). Pengelolaan alokasi dana desa dalam upaya meningkatkan pembangunan ekonomi masyarakat di desa magmagan karya kecamatan lumar. Jurnal Ekonomi 
683 Penyuluhan Hukum Terkait Penggunaan Dana Desa di Tengah Pandemi Covid-19- Yusrizal, Hadi Iskandar, Zulkifli, Romi Asmara, Ferdy Saputra, Hasan Basri, Muhammad Nasir

DOI: https://doi.org/10.31004/abdidas.v2i3.339

Daerah (JEDA), 7(1).

Mardiasmo. (2002). Otonomi dan manajemen keuangan daerah. Andi.

Ratnadila, N. S. (2018). Perencanaan Skenario untuk Pembangunan Desa Tertinggal: Sebuah Telaah Kritis. Jurnal Penyuluhan Perikanan Dan Kelautan, 12(2), 111-128.

Supriadi, E. (2015). Pertanggungjawaban kepala desa dalam pengelolaan keuangan desa berdasarkan undang-undang nomor 6 tahun 2014 tentang desa. Jurnal IUS Kajian Hukum Dan Keadilan, 3(2).

Wahyuningtyas, L. (2021). PERAN BADAN USAHA MILIK DESA (BUMDES) SEBAGAI UPAYA PENINGKATAN PENDAPATAN ASLI DESA (PADeS) DI DESA PUJONKIDUL KECAMATAN PUJON KABUPATEN MALANG. STIE PGRI Dewantara. 